\title{
Hyaluronidase in the correction of hyaluronic acid-based fillers: a review and a recommendation for use
}

\author{
Berthold Rzany, MD, ScM, ${ }^{1}$ Petra Becker-Wegerich, MD, ${ }^{2}$ Frank Bachmann, MD, ${ }^{1}$ Ricardo Erdmann, ${ }^{1}$ \\ \& Uwe Wollina, MD $^{3}$ \\ ${ }^{1}$ Division of Evidence-based Medicine, Klinik für Dermatologie, Charité Universitätsmedizin, Berlin, Deutschland \\ ${ }^{2}$ Ästhetik- und Laserzentrum, Meilen, Schweiz \\ ${ }^{3}$ Klinik für Dermatologie und Allergologie am Krankenhaus Dresden-Friedrichstadt, Dresden, Deutschland
}

\section{Summary}

Background Hyaluronic acid (HA) preparations are the most commonly used injectable fillers in esthetic medicine. In contrast to other injectable fillers with hyaluronidase, there is a tool available to reduce unwanted depots of this filler.

Aims The aim of this paper is to give an overview on the present literature and in addition to give some recommendations for use based on the experience of the authors. Methods The overview is based on a literature search.

Results There is some evidence from two smaller clinical trials that hyaluronidase will effectively decrease injected depots of HA. It has further been shown from case series and case reports that this reduction is clinically relevant. There is less evidence that hyaluronidase is also helpful in adverse reactions to HA-based fillers.

Conclusions The reports suggest that the treatment is safe. However, adverse reactions to hyaluronidase such as allergic reactions have been reported. Patient should be informed about that before treatment.

Keywords: hyaluronidase, hyaluronic acid

\section{Introduction}

Hyaluronic acid (HA)-based fillers are the most commonly used fillers. ${ }^{1,2}$ With the increased involvement of sometimes inexperienced colleagues and nonphysicians like nurses and nonmedical practitioners as beauticians and natural healers ('Heilpraktiker') the risk of unwanted results rises. Unwanted results can mean overcorrection and asymmetries as well as adverse events to these injectable fillers. Although hyaluronic-based fillers are defined as temporary materials, they can last up to 12 months or longer. ${ }^{3}$

Correspondence: Prof. Dr. med. B Rzany, Department of Dermatology, Division of Evidence Based Medicine, Charité Universitätsmedizin Berlin, Charitéplatz 1, D-10117 Berlin, Germany. E-mail: berthold.rzany@charite.de

Accepted for publication July 21, 2009
Hyaluronidase destroys HA and gives the possibility to adjust overcorrection and asymmetries. Furthermore, hyaluronidase has also been suggested for the treatment of the rare adverse reactions to HA fillers as by hypothesis some of the HA might still be present in the skin which might be targeted by hyaluronidase.

The aim of this review is to present the evidence for the efficacy and safety of hyaluronidase and to discuss proposals of use for this indication.

\section{Methodology}

Literature was searched through MEDLINE for case reports or case series on hyaluronidase in the treatment of unwanted HA depots or adverse reactions to HA. The search comprised all literature until August 2008. The literature was analyzed separately for papers focusing on the treatment of overcorrections and adverse reactions toward HA. 
Hyaluronidase in esthetic medicine - B Rzany et al.

Table 1 Summary of experimental studies in humans demonstrating the efficacy of hyaluronic acid in reducing the depots of injected hyaluronidase

\begin{tabular}{|c|c|c|c|c|c|}
\hline References & $\begin{array}{l}\text { No. of patients/ } \\
\text { gender/age }\end{array}$ & Setting & Study drug & Follow-up & $\begin{array}{l}\text { Adverse events to } \\
\text { hyaluronidase }\end{array}$ \\
\hline $\begin{array}{l}\text { Vartanian et al. }{ }^{4} \\
\text { (Part 1) }\end{array}$ & $\begin{array}{l}12 \text { subjects } / 7 \\
\text { female }(58 \%) \text {, } \\
5 \text { male }(42 \%) / \\
\text { Mean } \\
\text { age: } 43.7 \text { years }\end{array}$ & $\begin{array}{l}\text { Double-blinded, } \\
\text { randomized } \\
\text { clinical trial } \\
\text { Experimental design } \\
\text { Two ipsilateral forearm } \\
\text { injections of NASHA } \\
\text { gel each }\end{array}$ & $\begin{array}{l}0.5 \mathrm{~mL} \text { of } 0.9 \% \text { saline } \\
\text { or } 0.5 \mathrm{~mL} \text { of } \\
\text { hyaluronidase } \\
\text { (150 U/mL, equivalent to } \\
75 \mathrm{U} \text { of hyaluronidase) }\end{array}$ & $\begin{array}{l}\text { Dramatic decline in } \\
\text { palpation scores } \\
\text { occurred between } \\
\text { days } 4 \text { and } 7 \text { after } \\
\text { hyaluronidase injection }\end{array}$ & $\begin{array}{l}\text { All } 12 \text { patients (100\%) } \\
\text { reported more } \\
\text { burning sensation } \\
\text { during the } \\
\text { hyaluronidase } \\
\text { injection than during } \\
\text { the saline injection } \\
\text { Three patients (25\%) } \\
\text { developed localized } \\
\text { allergic reactions } \\
\text { (erythema, pruritus) to } \\
\text { the hyaluronidase } \\
\text { injections }\end{array}$ \\
\hline $\begin{array}{l}\text { Vartanian et al. }{ }^{4} \\
\text { (Part 2) }\end{array}$ & $\begin{array}{l}8 \text { volunteers } / 5 \\
\text { female } \\
(63 \%) / \text { Mean } \\
\text { age: } 38.1 \text { years }\end{array}$ & $\begin{array}{l}\text { Randomized blinded } \\
\text { evaluator } \\
\text { Randomly selected NASHA } \\
\text { gel injection sites ( } 0.2 \mathrm{~mL}) \\
\text { Received an equal } \\
\text { volume }(0.4 \mathrm{~mL} \text { ) of } \\
\text { one of three different } \\
\text { concentrations of } \\
\text { hyaluronidase }\end{array}$ & $\begin{array}{l}75 \mathrm{U} / \mathrm{mL} \text { (equivalent to } \\
30 \mathrm{U} \text { of hyaluronidase), } \\
50 \mathrm{U} / \mathrm{mL} \text { (equivalent } \\
\text { to } 20 \mathrm{U} \text { of } \\
\text { hyaluronidase), } \\
\text { or } 25 \mathrm{U} / \mathrm{mL} \\
\text { (equivalent to } 10 \mathrm{U} \text { of } \\
\text { hyaluronidase) } \\
\text { Thimerosal-free } \\
\text { hyaluronidase }\end{array}$ & $\begin{array}{l}\text { In all three groups, } \\
\text { skin palpation scores } \\
\text { declined } \\
\text { A dose-dependent } \\
\text { decline in the } \\
\text { palpation } \\
\text { scores could be found, } \\
\text { even though these } \\
\text { differences were not } \\
\text { statistically significant }\end{array}$ & $\begin{array}{l}\text { Two }(25 \%) \text { of the } \\
\text { eight subjects developed } \\
\text { mild localized allergic } \\
\text { responses } \\
\text { No other adverse } \\
\text { reactions were noticed }\end{array}$ \\
\hline
\end{tabular}

\section{Results}

We were able to find several papers focusing on hyaluronidase as a corrective tool for HA in esthetic medicine.

Two experimental studies focused on the principals of efficacy of hyaluronidase in reducing depots of HA.

\section{Experimental studies in humans}

These two small prospective randomized studies $(n=12$ and $n=8$ ) were conducted sequentially by Varatian et al. $^{4}$ to determine the efficacy and dose dependency of hyaluronidase on NASHA gel implants (Table 1). The first arm of the study was intended to compare the effects of injected hyaluronidase or saline on sites of previous NASHA gel injections. The second arm was designed to evaluate the dose-dependent effects of injected hyaluronidase on NASHA gel augmentation sites.

These are quite small experimental studies and, in fact, there was only a trend of a dose-response relationship. However, they demonstrate the efficacy of hyaluronidase in reducing small amounts of injected HA.

Efficacy of hyaluronidase in reducing unwanted depots of hyaluronic acid

Most papers focus on the effect of hyaluronidase in reducing unwanted depots of HA (Table 2).
In addition to these case reports, one large case series can be found. The purpose of the case series comprising 155 patients was to describe the authors' experience with the treatment of periorbital hollows with HA (Restylane, Q-Med, Uppsala, Sweden). ${ }^{5}$ For some reason, $11 \%$ of patients $(n=17)$ received hyaluronidase to reduce contour irregularities. The typical dose used was 0.3-1.0 $\mathrm{mL}$ of a $15 \mathrm{U} / \mathrm{mL}$ solution. The authors report incomplete response to the attempts to decrease the residual HA gel by using hyaluronidase injections when the unwanted effect was a doughy edema.

In addition, two papers could be found that focused on the reduction of HA depots in patients with probable vascular reactions (Table 3 ).

Hyaluronidase to reduce the effects of adverse reactions to hyaluronic acid preparations

Three papers could be found focusing on the effect of hyaluronidase on the treatment of adverse reactions to HA (Table 4).

Safety of hyaluronidase

Adverse reactions to hyaluronidase are rare. In his case series, e.g., Sopokar et al. ${ }^{6}$ reported only in 2 of 97 treated patients a temporary postinjection pruritus. However, allergic and even a few anaphylactic reactions have been associated with hyaluronidase. Most reports 
Table 2 Case reports on hyaluronidase reducing unwanted depots of hyaluronic acid preparations

\begin{tabular}{|c|c|c|c|c|c|}
\hline References & $\begin{array}{l}\text { No. of } \\
\text { patients, } \\
\text { gender, age }\end{array}$ & Diagnosis & $\begin{array}{l}\text { Hyaluronidase } \\
\text { used }\end{array}$ & Follow-up & $\begin{array}{l}\text { Adverse events } \\
\text { to hyaluronidase }\end{array}$ \\
\hline Lambros ${ }^{17}$ & $\begin{array}{l}1 \text { female } \\
\text { patient, } \\
35 \text { years old }\end{array}$ & $\begin{array}{l}\text { Lumpiness } \\
\text { after HA injections }\end{array}$ & $\begin{array}{l}75 \text { Units of hyaluronidase } \\
\text { (Lee Pharmacy, Inc.; } 50 \mathrm{U} / \mathrm{cc} \text { ) } \\
\text { and } 1.5 \mathrm{cc} \text { of } 0.5 \% \text { lidocaine } \\
\text { with epinephrine }\end{array}$ & $\begin{array}{l}\text { Successful dissolution: } \\
90 \% \text { in } 24 \mathrm{~h}\end{array}$ & None \\
\hline Soparkar et al. ${ }^{21}$ & $\begin{array}{l}1 \text { female } \\
\text { patient, } \\
65 \text { years old }\end{array}$ & $\begin{array}{l}\text { Persistent sausage } \\
\text { whisker-like reaction } \\
\text { immediately after } \\
\text { Restylane } \\
\text { injection } 63 \text { months ago }\end{array}$ & $\begin{array}{l}100 \mathrm{U} / \mathrm{mL} \text {, using } \\
0.025-0.05 \mathrm{~mL} \\
\text { at each side (local } \\
\text { pharmacist) }\end{array}$ & $\begin{array}{l}\text { One week } \\
\text { later => complete } \\
\text { resolution of the } \\
\text { "sausage whiskers" }\end{array}$ & None \\
\hline Hirsch et al. ${ }^{18}$ & $\begin{array}{l}1 \text { female } \\
\text { patient, } \\
44 \text { years old }\end{array}$ & $\begin{array}{l}\text { Bluish discoloration after } \\
\text { Juvéderm }{ }^{\mathrm{TM}} \text { (Allergan, Inc., } \\
\text { Irvine, CA, USA) injection } \\
\text { from a nonexperienced } \\
\text { injector }\end{array}$ & $\begin{array}{l}75 \text { Units of hyaluronidase } \\
\text { enzyme (Vitrase }{ }^{\mathrm{TM}} \text {, } \\
\text { IstaPharmaceuticals) } \\
\text { Further } 75 \text { units several } \\
\text { days later }\end{array}$ & $\begin{array}{l}\text { First improvement } \\
\text { within } 4 \text { days, } \\
\text { complete clearance }\end{array}$ & None mentioned \\
\hline Hirsch and Cohen ${ }^{19}$ & $\begin{array}{l}1 \text { female, } \\
\text { patient, } \\
56 \text { years old }\end{array}$ & $\begin{array}{l}\text { Blue-gray infraorbital } \\
\text { nodule } 2 \text { weeks } \\
\text { post-Restylane } \\
\text { injection in the } \\
\text { nasojugal folds }\end{array}$ & $\begin{array}{l}75 \text { Units of amphadase } \\
\text { was immediately } \\
\text { injected into and around } \\
\text { the infraorbital nodule }\end{array}$ & $\begin{array}{l}\text { Within } 72 \mathrm{~h} \text { almost } \\
\text { complete resolution } \\
\text { of the lump }\end{array}$ & None \\
\hline Andre and Levy 22 & $\begin{array}{l}1 \text { female, } \\
\text { patient } \\
25 \text { years old }\end{array}$ & $\begin{array}{l}\text { HA injection } 1 \text { month } \\
\text { ago; soft, } \\
\text { lumpy, bluish mass; } \\
\text { overcorrection } \\
\text { (blue mass) periocular } \\
\text { after HA injection } \\
\text { (Surgiderm 30XP) }\end{array}$ & $\begin{array}{l}\text { 4\% Ovine-derived } \\
\text { hyaluronidase } \\
\text { (Desinfitral; Aesthetic } \\
\text { Dermal, Girona, Spain) } \\
\text { (1 vial } 1500 \text { IU. diluted } \\
\text { with } 4 \mathrm{~mL} \text { ) } \\
\text { Injection of } \\
0.3 \mathrm{~mL}=150 \mathrm{U}\end{array}$ & $\begin{array}{l}\text { Within } 10 \text { min already } \\
\text { some effects, after } 1 \mathrm{~h} \\
\text { approximately } 50 \% \text { of } \\
\text { the mass had already } \\
\text { disappeared, after } 12 \mathrm{~h} \\
\text { complete disappearance }\end{array}$ & $\begin{array}{l}\text { No pain during } \\
\text { treatment } \\
\text { No adverse events }\end{array}$ \\
\hline $\begin{array}{l}\text { Brody }{ }^{23} \\
\text { (see also below) }\end{array}$ & $\begin{array}{l}\text { (1) 64-year-old } \\
\text { patient } \\
\text { (2) } 45 \text {-year-old } \\
\text { female } \\
\end{array}$ & $\begin{array}{l}\text { (1) Pearly, contiguous, } \\
\text { slightly blue, } \\
\text { soft mass under } \\
\text { each eye } \\
\text { (2) Left side of her } \\
\text { nasolabial fold } \\
\text { was larger than } \\
\text { her right and } \\
\text { she thought that } \\
\text { the material "moved } \\
\text { over into the fold" }\end{array}$ & $\begin{array}{l}\text { (1) } 1 \mathrm{cc} \text { of } 75 \text { units } \\
\text { of hyaluronidase } \\
(150 \text { units/cc) } \\
\text { combined with } 1.5 \mathrm{cc} \text { of } \\
1 \% \text { lidocaine } \\
\text { with epinephrine } \\
\text { (2) } 0.5 \mathrm{cc} \text { of a solution } \\
\text { of } 75 \text { units of } \\
\text { hyaluronidase mixed } \\
\text { with } 1 \% \text { lidocaine } \\
\text { with epinephrine }\end{array}$ & $\begin{array}{l}\text { (1) Disappearance } \\
\text { of most of the } \\
\text { material within } 24 \mathrm{~h} \text {; } \\
\text { reinjection or remaining } \\
\text { nodules with } 0.1 \mathrm{cc} \\
\text { of hyaluronidase } \\
\text { Solution with dissolution } \\
\text { of the remaining material } \\
\text { within } 5 \text { days } \\
\text { (2) Little improvement => } \\
\text { her left side has always } \\
\text { been slightly larger than } \\
\text { that on her right side }\end{array}$ & $\begin{array}{l}\text { (1) Mild erythema; } \\
\text { mild ecchymosis } \\
\text { (2) Slight erythema } \\
\text { within } 24 \mathrm{~h}\end{array}$ \\
\hline
\end{tabular}

are based on ophthalmological or other nonesthetic interventions. ${ }^{7-10}$ In addition, a couple of reports after the use of ovine as well as bovine hyaluronidase for esthetic indications can be found ${ }^{11}$ (Becker-Wegerich 2009, personal communication). In both cases, edema developed rapidly after the injection. The edema was controlled by steroid injections.

\section{Available hyaluronidase preparations in Europe (Table 5)}

Most available hyaluronidase products use hyaluronidase of bovine origin. In addition, hyaluronidase of ovine origin exists.
Hylase "Dessau"

Hyaluronidase (Hylase ${ }^{\circledR}$ “Dessau”, Riemser Arzneimittel AG, Greifswald - Insel Riems, Germany) was developed as a spreading or diffusing substance to increase the permeability of connective tissue through the hydrolysis of HA. The enzyme is extracted from bovine testes. The bovine testes used are obtained from New Zealand from a source which is recognized as being completely BSE (Bovine Spongiform Encephalopathy) free.

Hyaluronidase is an enzyme that breaks down HA (hyaluronan) by cleaving glycosidic bonds of HA and, to some extent, other acid mucopolysaccharides of the 
Hyaluronidase in esthetic medicine - B Rzany et al.

Table 3 Case reports focusing on the effects of hyaluronidase in impending vascular reactions

\begin{tabular}{|c|c|c|c|c|c|}
\hline References & $\begin{array}{l}\text { No. of } \\
\text { patients/ } \\
\text { gender/age }\end{array}$ & Diagnosis & Hyaluronidase used & Follow-up & $\begin{array}{l}\text { Adverse events } \\
\text { to hyaluronidase }\end{array}$ \\
\hline Hirsch et al. $2007^{24}$ & $\begin{array}{l}1 \text { female patient/ } \\
44 \text { years old }\end{array}$ & $\begin{array}{l}\text { Probable vascular } \\
\text { reaction with impending } \\
\text { necrosis after treatment } \\
\text { of the nasolabial fold }\end{array}$ & $\begin{array}{l}30 \text { Units of hyaluronidase } \\
\text { (exact product } \\
\text { information } \\
\text { not given) } \\
\text { In addition pretreatment } \\
\text { aspirin p.o. and topical } \\
\text { nitroglycerin paste as } \\
\text { well as hot compresses }\end{array}$ & $\begin{array}{l}\text { Eight hours later } \\
\text { the lip and area } \\
\text { previously observed } \\
\text { to be under vascular } \\
\text { compromise was } \\
\text { pinkish; } 2 \text { weeks } \\
\text { later there was no } \\
\text { evidence of any } \\
\text { residual adverse event }\end{array}$ & None \\
\hline Hirsch et al. ${ }^{25}$ & $\begin{array}{l}1 \text { female patient/ } \\
43 \text { years old }\end{array}$ & $\begin{array}{l}>48 \mathrm{~h} \text { after injection of } \\
\text { the nasolabial fold } \\
\text { patchy cutaneous } \\
\text { erythema and } \\
\text { violaceous foci }\end{array}$ & 30 Units of hyaluronidase & $\begin{array}{l}\text { Day } 3 \text { after hyaluronidase } \\
\text { injection: continuing } \\
\text { improvement in pain, } \\
\text { color and physical } \\
\text { appearance }\end{array}$ & None \\
\hline
\end{tabular}

Table 4 Effect of hyaluronidase on the improvement of adverse reactions to hyaluronic acid preparations

\begin{tabular}{|c|c|c|c|c|c|}
\hline References & $\begin{array}{l}\text { No. of } \\
\text { patients/ } \\
\text { gender/age }\end{array}$ & Diagnosis & $\begin{array}{l}\text { Hyaluronidase } \\
\text { used }\end{array}$ & Follow-up & $\begin{array}{l}\text { Adverse events to } \\
\text { hyaluronidase }\end{array}$ \\
\hline $\begin{array}{l}\text { Soparkar } \\
\text { and Patrinely }{ }^{26}\end{array}$ & $\begin{array}{l}\text { 62-year-old } \\
\text { woman }\end{array}$ & $\begin{array}{l}\text { Severe dermal } \\
\text { inflammatory } \\
\text { reaction to } \\
\text { Restylane }\end{array}$ & $\begin{array}{l}\text { A total of five injections } \\
\text { accounting for } 375 \text { units } \\
\text { of hyaluronidase } \\
\text { over a period of } \\
2 \text { weeks } \\
\text { Patient received in } \\
\text { addition oral Levofloxacin } \\
\text { and oral steroids }\end{array}$ & $\begin{array}{l}\text { Good results } \\
\text { after } 4 \text { months }\end{array}$ & None \\
\hline $\begin{array}{l}\text { Brody }^{23} \\
\text { (see above) }\end{array}$ & $\begin{array}{l}\text { 68-year-old } \\
\text { female }\end{array}$ & $\begin{array}{l}\text { Within } 1 \text { week } \\
\text { after injection => } \\
\text { redness, bumpiness, } \\
\text { tenderness, and warmth; } \\
\text { multiple warm, red, } \\
\text { indurated nodules } \\
\text { after nonanimal-stabilized } \\
\text { hyaluronic acid; additional } \\
\text { bovine collagen }\end{array}$ & $\begin{array}{l}15 \text { Units ( } 0.2 \mathrm{cc} \text { of a } \\
\text { solution of } 75 \text { units) of } \\
\text { hyaluronidase combined } \\
\text { with } 1 \% \text { lidocaine with } \\
\text { epinephrine as well as topical } \\
\text { steroids and oral antibiotics } \\
\text { and weekly courses } \\
\text { of prednisone }\end{array}$ & $\begin{array}{l}\text { Within } 24 \mathrm{~h} \text {, the } \\
\text { patient noted the } \\
\text { disappearance of the } \\
\text { nodule without } \\
\text { recurrence }\end{array}$ & None \\
\hline Becker-Wegerich ${ }^{27}$ & $\begin{array}{l}1 \text { female patient/ } \\
49 \text { years old }\end{array}$ & $\begin{array}{l}\text { Approximately } 1 \mathrm{~cm} \text { large } \\
\text { and bluish nodules } \\
8 \text { months } \\
\text { after the injection } \\
\text { of Restylane } \\
\text { Vital in the dorsum } \\
\text { of the hand }\end{array}$ & $\begin{array}{l}\text { Hyaluronidase (Hylase Dessau) } \\
\text { two injections with } 0.2 \mathrm{~mL} \\
\text { per node, } 3 \text { days from each } \\
\text { apart ( } 150 \text { units were diluted } \\
\text { with } 1 \mathrm{~mL} \text { saline) }\end{array}$ & $\begin{array}{l}\text { Flattening of the } \\
\text { nodules }\end{array}$ & None \\
\hline
\end{tabular}

Table 5 Available hyaluronidase preparations in Europe

\begin{tabular}{|c|c|c|c|c|}
\hline Name & Company & Units per vial & Origin & References \\
\hline Hylase Dessau & Riemser Arzneimittel AG, Germany & $150 *, 300,1500$ & Bovine & 12 \\
\hline Desinfitral & Aesthetic Dermal, UK & 1500 & Ovine & 22 \\
\hline
\end{tabular}

*Usually the 150-U vial is sufficient when used to remove unwanted depots of hyaluronic acid. 
connective tissue. ${ }^{12}$ The physiologic role of hyaluronidase is seen in stimulating angiogenesis by defragmenting HA. The fibrotic healing of adult and late gestational wounds correlates with an increased hyaluronidase activity and a removal of hyaluronan. ${ }^{13}$ Further consideration see hyaluronidase as a regulatory agent in HA homeostasis and metabolism. ${ }^{14}$ Hyaluronidase cannot cross the blood-brain barrier. ${ }^{15}$ The clinical use and therapeutic benefits of hyaluronidase began in the early 1950s. In 1952, Breu discovered that the enzyme is capable of spreading dyes or other substances in tissue and of significantly increasing the permeability of skin and connective tissue via the breakdown of HA. The enzyme hyaluronidase is a "hydrolase" with a molecular weight of approximately $60000 \mathrm{Da}^{16}$

Hylase $^{\circledR}$ "Dessau" comes as a white powder which needs to be diluted with saline before injection. The smallest vial available contains $150 \mathrm{U}$. The product contains no preservatives. The product is manufactured during a sophisticated multistep procedure established and patented in Germany for many decades. It is a highly purified bovine protein extract with a low allergic or sensitizing potential.

Hylase $^{\circledR}$ "Dessau" must be stored at cool temperatures $\left(2-8{ }^{\circ} \mathrm{C}\right)$. These conditions guarantee the constant quality of the product over a long period. Additional tests have shown the stability of the product at controlled room temperature $\left(25^{\circ} \mathrm{C} \pm 2{ }^{\circ} \mathrm{C} / 60 \%\right.$ relative humidity $[\mathrm{RH}] \pm 5 \% \mathrm{RH}$ ) over a period of at most 12 months (Supplementary Protection Certificate).

\section{Other hyaluronidase preparations}

In the literature, several other hyaluronidase preparations were used. In the earlier papers, hyaluronidase derived from Lee Pharmacy, Inc., Fort Smith, AZ, USA; $50 \mathrm{U} / \mathrm{cc}^{17}{ }^{17}$ Hirsch et al. ${ }^{18,19}$ used Vitrase ${ }^{\mathrm{TM}}$, IstaPharmaceuticals (http://www.istavision.com/products/ products_vitrase200.asp). Vitrase is a preparation of purified ovine (sheep) testicular hyaluronidase, a protein enzyme. It contains an active component: 200 USP units/mL of ovine hyaluronidase. Amphadase (Amphastar Pharmaceuticals, Inc., Rancho Cucamonga, CA, USA), another hyaluronidase product, is also a preparation of a bovine source. Each vial contains 150 USP units of hyaluronidase per $\mathrm{mL}$.

Hylenex ${ }^{\circledR}$ recombinant (Baxter Healthcare Corporation and Halozyme Therapeutics, Inc.) is a purified preparation of recombinant hyaluronidase from Chinese Hamster Ovary cells. The purified glycoprotein contains 447 amino acids and has a molecular weight of approximately 61000 Da. Each milliliter of this preparation contains 150 USP units of recombinant human hyaluronidase per milliliter. ${ }^{20}$

\section{Practical consideration}

Although there are no large randomized-controlled trials on the efficacy of hyaluronidase in reducing unwanted depots of HA, based on the reviewed literature and based on the personal experience of the authors some practical considerations can be given.

In the case of unwanted depots of HA, the following steps should be performed:

- Inform the patient that hyaluronidase is not licensed so far for the treatment of unwanted HA depots.

- Inform also the patient that in rare cases, adverse reactions to the hyaluronidase have been known. Do NOT skin test. The allergic reactions are quite rare and cannot totally be excluded by skin test.

- Do NOT treat patients with a known allergy to bovine protein if the hyaluronidase used derives from bovine material.

- Dilute the hyaluronidase (150 U vial) with $0.9 \%$ saline $(1 \mathrm{~mL})$ and inject the mixture in the HA depots. There is NO evidence that the addition of lidocaine or epinephrine is helpful. The volume used depends on the quantity of injected HA. Usually $0.05-0.1 \mathrm{~mL}$ per injection point (7.5-15 U) is sufficient. Inject slowly.

- Choose the needle size according to the location and the size of the depot. Use a 30 -gauge $(0.3 \times 13 \mathrm{~mm})$ needle for more superficial nodules and a 27 -gauge $(0.4 \times 20 \mathrm{~mm})$ or a 26 -gauge $(0.45 \times 10 \mathrm{~mm})$ needle for deeper nodules.

- Make sure to inject in the HA depot; in cases of very superficial HA depots, inject just beneath the depot.

- For nodules exclusively due to HA, some patients notice an obvious decrease or a disappearance of the nodule within $24-48 \mathrm{~h}$. For nodules of unknown cause, an obvious reduction of inflammation and size has been induced in some patients. Usually, an apparent regression is noticeable within $24-48 \mathrm{~h}$; however, in inflamed nodules a complete disappearance may take longer. Therefore, a control visit should be scheduled about 2 weeks after the injection.

- If the nodule is very inflamed and an abscess may be likely an adjuvant systemic antibiotic treatment, e.g., with ciprofloxacine or levofloxacine $250 \mathrm{mg}$ once daily, should be initiated as hyaluronidase may act as the spreading factor.

- For the same reason (potentially increased spreading) hyaluronidase should not be injected in an area that has been treated with botulinum toxin A in the last $48 \mathrm{~h}$. 
- If an immediate reaction occurs treat accordingly to the prevailing symptoms. As for every allergic reaction, an allergy pass card should be issued. Furthermore, an allergological workup is recommended.

\section{Conclusions}

HA preparations are the most used injectable fillers on the market. As the esthetic market is growing, more and more patients will be treated with HA. This will lead to more patients with a relative or absolute overcorrection and patients who suffer from immediate or long-term adverse events from these products. A product like hyaluronidase can therefore be considered as a rescuemedication which can help reverse overcorrection or some more severe complications.

There is some evidence from two smaller clinical trials that hyaluronidase will effectively decrease injected depots of HA. There is further evidence from case series and case reports that this reduction is clinically relevant. There is very little evidence that hyaluronidase is also helpful in adverse reactions to HA-based fillers.

The reports suggest that the treatment is safe. However, adverse reactions, as allergic reactions, to hyaluronidase of bovine or ovine origin have been reported. Patients should be informed about that before treatment.

Colleagues should be instructed about this very beneficial tool and how it should be used.

\section{References}

1 De Maio M, Rzany B. Injectable Fillers in Aesthetic Medicine. Heidelberg: Springer; 2006; ISBN 3-540-23941-3.

2 Monheit GD, Coleman KM. Hyaluronic acid fillers. Dermatol Ther 2006; 19(3): 141-50.

3 Narins RS, Dayan SH, Brandt FS, Baldwin EK. Persistence and improvement of nasolabial fold correction with nonanimal-stabilized hyaluronic acid 100,000 gel particles/mL filler on two retreatment schedules: results up to 18 months on two retreatment schedules. Dermatol Surg 2008; 34(Suppl. 1): S2-8.

4 Vartanian AJ, Frankel AS, Rubin MG. Injected hyaluronidase reduces restylane-mediated cutaneous augmentation. Arch Facial Plast Surg 2005; 7(4): 231-7.

5 Goldberg RA, Fiaschetti D. Filling the periorbital hollows with hyaluronic acid gel: initial experience with 244 injections. Ophthal Plast Reconstr Surg 2006; 22(5): 335-41.

6 Soparkar CN, Patrinely JR, Skibell BC, Tower RN. Hyaluronidase and Restylane. Arch Facial Plast Surg 2007; 9(4): 299-300.

7 Agrawal A, McLure HA, Dabbs TR. Allergic reaction to hyaluronidase after a peribulbar injection. Anaesthesia 2003; 58(5): 493-4.
8 Ahluwalia HS, Lukaris A, Lane CM. Delayed allergic reaction to hyaluronidase: a rare sequel to cataract surgery. Eye 2003; 17(2): 263-6.

9 Leibovitch I, Tamblyn D, Casson R, Selva D. Allergic reaction to hyaluronidase: a rare cause of orbital inflammation after cataract surgery. Graefes Arch Clin Exp Ophthalmol 2006; 244(8): 944-9.

10 Müller U, Bircher A, Bischof M. Allergisches Angioödem nach zahnärztlicher Applikation eines Lokalanästhetikum und Hyaluronidase enthaltenden Vorspritzmittels. Schweiz Med Wochenschr 1986; 116: 1810-1813.

11 Andre P, Flechet ML. Angioedema after ovine hyaluronidase injection for treating hyaluronic acid overcorrection. J Cosmet Dermatol 2008; 7(2): 136-8.

12 European Pharmacopoeia 6.0: European Directorate for the Quality of Medicines; 2008; 978-92-871-6328-8 (online). http://www.digento.de/titel/103336.html.

13 West DC, Shaw DM, Lorenz P, Adzick NS, Longaker MT. Fibrotic healing of adult and late gestation fetal wounds correlates with increased hyaluronidase activity and removal of hyaluronan. Int J Biochem Cell Biol 1997; 29(1): 201-10.

14 Schwartz DM, Jumper MD, Lui GM, Dang S, Schuster S, Stern R. Corneal endothelial hyaluronidase: a role in anterior chamber hyaluronic acid catabolism. Cornea 1997; 16(2): 188-91.

15 Jiang D, Liang J, Noble PW. Hyaluronan in tissue injury and repair. Annu Rev Cell Dev Biol 2007; 23: 435-61.

16 Breu W. Hyaluronidase. Wien Med Wochenschr 1952; 102(23): 435-7.

17 Lambros V. The use of hyaluronidase to reverse the effects of hyaluronic acid filler. Plast Reconstr Surg 2004; 114(1): 277.

18 Hirsch RJ, Narurkar V, Carruthers J. Management of injected hyaluronic acid-induced Tyndall effects. Lasers Surg Med 2006; 38(3): 202-4.

19 Hirsch RJ, Cohen JL. Challenge: Correcting superficially placed hyaluronic acid. Skin Aging 2007; 15: 36-8.

20 Yocum RC, Kennard D, Heiner LS. Assessment and implication of the allergic sensitivity to a single dose of recombinant human hyaluronidase injection: a doubleblind, placebo-controlled clinical trial. J Infus Nurs 2007; 30(5): 293-9.

21 Soparkar CN, Patrinely JR, Tschen J. Erasing restylane. Ophthal Plast Reconstr Surg 2004; 20(4): 317-8.

22 Andre P, Levy PM. Hyaluronidase offers an efficacious treatment for inaesthetic hyaluronic acid overcorrection. J Cosmet Dermatol 2007; 6(3): 159-62.

23 Brody HJ. Use of hyaluronidase in the treatment of granulomatous hyaluronic acid reactions or unwanted hyaluronic acid misplacement. Dermatol Surg 2005; 1: 893-7.

24 Hirsch RJ, Cohen JL, Carruthers JD. Successful management of an unusual presentation of impending necrosis following a hyaluronic acid injection embolus and a proposed algorithm for management with hyaluronidase. Dermatol Surg 2007; 33(3): 357-60. 
25 Hirsch RJ, Lupo M, Cohen JL, Duffy D. Delayed presentation of impending necrosis following soft tissue augmentation with hyaluronic acid and successful management with hyaluronidase. J Drugs Dermatol 2007; 6(3): 325-8.

26 Soparkar CN, Patrinely JR. Managing inflammatory reaction to restylane. Ophthal Plast Reconstr Surg 2005; 21(2): 151-3.
27 Becker-Wegerich P. New indications for Hyaluronic acid of the NASHA-gel-generation-highlights from aesthetical dermatology in clinical daily routine. J Dtsch Dermatol Ges 2008; 6(Suppl. 3): S3-20. 